\title{
Interactions of Water Vapor with Oxides at Elevated Temperatures
}

\author{
Nathan Jacobson \\ NASA Glenn Research Center \\ Cleveland, $\mathrm{OH} 44135$ \\ Elizabeth Opila \\ Cleveland State University/NASA Glenn Research Center \\ Cleveland, $\mathrm{OH} 44135$ \\ Evan Copland \\ Case Western Reserve University/NASA Glenn Research Center \\ Cleveland, $\mathrm{OH} 44135$ \\ Dwight Myers \\ East Central University \\ Ada, OK 74820
}

\begin{abstract}
Many volatile metal hydroxides form by reaction of the corresponding metal oxide with water vapor. These reactions are important in a number of high temperature corrosion processes. Experimental methods for studying the thermodynamics of metal hydroxides include: gas leak Knudsen cell mass spectrometry, free jet sampling mass spectrometry, transpiration and hydrogen-oxygen flame studies. The available experimental information is reviewed and the most stable metal hydroxide species are correlated with position in the periodic table. Current studies in our laboratory on the $\mathrm{Si}-\mathrm{O}-\mathrm{H}$ system are discussed.
\end{abstract}

\section{Introduction-Importance of Volatile Hydroxides in Corrosion}

A number of elements form volatile hydroxides of the general formula $\mathrm{M}(\mathrm{OH})_{\mathrm{n}}$ or oxyhydroxides of the general formula $\mathrm{MO}_{\mathrm{p}}(\mathrm{OH})_{\mathrm{q}}$. These form by either of two reaction routes $[1,2]$ :

Hydroxides $(\mathrm{s}, 1)=$ Hydroxide $(\mathrm{g})$

$$
\text { e.g. } \mathrm{KOH}(\mathrm{s})=\mathrm{KOH}(\mathrm{g})
$$


Oxide $(\mathrm{s}, \mathrm{l})+\mathrm{H}_{2} \mathrm{O}(\mathrm{g})=$ Hydroxide $(\mathrm{g})$ or Oxy-hydroxide $(\mathrm{g})$

$$
\begin{aligned}
& \text { e.g. } \mathrm{BeO}(\mathrm{s})+\mathrm{H}_{2} \mathrm{O}(\mathrm{g})=\mathrm{Be}(\mathrm{OH})_{2}(\mathrm{~g}) \\
& \text { e.g. } \mathrm{MoO}_{3}(\mathrm{~s})+\mathrm{H}_{2} \mathrm{O}(\mathrm{g})=\mathrm{MoO}_{2}(\mathrm{OH})_{2}(\mathrm{~g})
\end{aligned}
$$

Here we shall focus on reactions of the second type, which are important in a number of high-temperature corrosion processes. Many high temperature corrosion processes occur in combustion environments. Generally hydrocarbon fuel combustion atmospheres contain $\sim 10 \%$ water vapor [3]. For 1 bar total pressure, 0.1 bar water vapor is formed; for higher pressure combustion processes an even higher pressure of water vapor is formed. Further, combustion processes in a heat engine typically involve rapidly flowing gases. Together with reaction route (2) this leads to a substantial removal of material.

There are numerous examples of metal hydroxide formation in corrosion processes. Zaplatynsky [4] has exposed a number of commercial Ni-base alloys to air at $1200^{\circ} \mathrm{C}$. Depending on the alloy, he observed volatilization of tungsten, molybdenum, niobium, manganese, and chromium from surface oxides. Some of this is due to volatile oxides; but Krikorian [5] points out that the presence of moisture in laboratory air could also create high volatility hydroxides and oxy-hydroxides during high temperature exposure.

A number of authors have studied chromia vaporization experimentally and provided supporting thermodynamic calculations. It is well-known that chromia vaporizes in an oxidative environment [6-8]:

$\mathrm{Cr}_{2} \mathrm{O}_{3}(\mathrm{~s})+3 / 2 \mathrm{O}_{2}(\mathrm{~g})=2 \mathrm{CrO}_{3}(\mathrm{~g})$

A plot of the vapor pressure of $\mathrm{CrO}_{3}(\mathrm{~g})$ from $\mathrm{Cr}_{2} \mathrm{O}_{3}$ with $21 \% \mathrm{O}_{2} / 79 \% \mathrm{Ar}$ is shown in Figure 1 . The addition of $10 \%$ water vapor enhances volatility even further from the reaction $[8,9]$ :

$\mathrm{Cr}_{2} \mathrm{O}_{3}(\mathrm{~s})+2 \mathrm{H}_{2} \mathrm{O}(\mathrm{g})+3 / 2 \mathrm{O}_{2}(\mathrm{~g})=2 \mathrm{CrO}_{2}(\mathrm{OH})_{2}(\mathrm{~g})$ 
The vapor pressure of $\mathrm{CrO}_{2}(\mathrm{OH})_{2}(\mathrm{~g})$ from $\mathrm{Cr}_{2} \mathrm{O}_{3}(\mathrm{~s})+21 \% \mathrm{O}_{2} / 10 \% \mathrm{H}_{2} \mathrm{O} / 69 \% \mathrm{Ar}$ is also shown in Figure 1. Note the higher vapor pressure of $\mathrm{CrO}_{2}(\mathrm{OH})_{2}(\mathrm{~g})$ than $\mathrm{CrO}_{3}(\mathrm{~g})$. Similar oxy-hydroxides from Mo and $\mathrm{W}$ are thought to play a role in the degradation of Mo emitter materials [10] and W filaments in lamps [2].

Boron is commonly proposed as a constituent in high temperature materials. Transition metal borides have extremely high melting points [11], boron is used as an oxidation inhibiter in carbon [12], and boron nitride (BN) is used as a fiber coating in continuous fiber reinforced ceramic matrix composites [13]. However, the oxy-hydroxide of boron forms readily from boric oxide:

$\mathrm{B}_{2} \mathrm{O}_{3}(\mathrm{~s})+\mathrm{H}_{2} \mathrm{O}(\mathrm{g})=2 \mathrm{BO}(\mathrm{OH})(\mathrm{g})$

The BN fiber coating in composites has been observed to vaporize [13] in moisturecontaining environments at temperatures as low as $500^{\circ} \mathrm{C}$, very likely by $\mathrm{BN}$ oxidation to $\mathrm{B}_{2} \mathrm{O}_{3}$ and subsequent vaporization to $\mathrm{BO}(\mathrm{OH})(\mathrm{g})$.

Silicon-based ceramics, such as silicon carbide $(\mathrm{SiC})$ and silicon nitride $\left(\mathrm{Si}_{3} \mathrm{~N}_{4}\right)$, and composites of these are promising high temperature materials. These materials rely on a thin film of thermally grown silica $\left(\mathrm{SiO}_{2}\right)$ for corrosion protection. In dry oxygen, this film is remarkably durable, however in high-temperature water-vapor containing environments, this film vaporizes according to:

$\mathrm{SiO}_{2}(\mathrm{~s})+\mathrm{H}_{2} \mathrm{O}(\mathrm{g})=\mathrm{Si}(\mathrm{OH})_{4}(\mathrm{~g})$

Oxidation of the $\mathrm{SiC}$ or $\mathrm{Si}_{3} \mathrm{~N}_{4}$ substrate occurs concurrently with the volatilization reaction (7) and can lead to substantial material loss over long periods of time [14-16].

There is also evidence of volatile hydroxide formation with $\mathrm{Al}_{2} \mathrm{O}_{3}$ and $\mathrm{ZrO}_{2}$. Tai et al. [17] have observed substantially more grain boundary etching on $\mathrm{Al}_{2} \mathrm{O}_{3}$ in an $\mathrm{Ar} / \mathrm{H}_{2} \mathrm{O}$ environment as compared to a pure $\mathrm{Ar}$ environment at $1700^{\circ} \mathrm{C}$. This is attributed to 
$\mathrm{Al}(\mathrm{OH})_{3}(\mathrm{~g})$ formation. Etori et al. [18] have observed weight losses of $\mathrm{Al}_{2} \mathrm{O}_{3}$ and $\mathrm{ZrO}_{2}$ in a petroleum gas burner at $1500^{\circ} \mathrm{C}, 1.8$ bar total pressure, and a gas velocity of $150 \mathrm{~m} / \mathrm{s}$. The gas atmosphere contained $9.5 \% \mathrm{H}_{2} \mathrm{O}$. They suggested the possibility of metal hydroxide formation, although no further evidence such as a downstream deposit was observed. Recently, Yuri and Hisamatu [19] have done further studies on $\mathrm{Al}_{2} \mathrm{O}_{3}$ weight loss in a burner and observed a water vapor pressure dependence of near 1.5, suggesting the reaction:

$1 / 2 \mathrm{Al}_{2} \mathrm{O}_{3}+3 / 2 \mathrm{H}_{2} \mathrm{O}(\mathrm{g})=\mathrm{Al}(\mathrm{OH})_{3}(\mathrm{~g})$

In summary there are a number of applications where volatile hydroxides play a key role. Thus it is essential to understand the thermodynamics of these species so we can predict their corrosion rates.

\section{Techniques for Studying Thermodynamics of Metal Hydroxides}

Thermodynamic studies of metal hydroxides require highly oxidizing environments and the most common method for studies of high temperature vapors, based on the Knudsen cell, requires a more reducing environment. Hence the Knudsen cell technique must be adapted for water vapor studies. There are several studies in the literature of hydroxides using gas-leak Knudsen cell mass spectrometry [20-27] . Here a small amount of water vapor is admitted to a Knudsen cell to react with an oxide. Alternatively $\mathrm{H}_{2}(\mathrm{~g})$ or $\mathrm{D}_{2}(\mathrm{~g})$ may be admitted which reacts with the oxide to form $\mathrm{H}_{2} \mathrm{O}(\mathrm{g})$ or $\mathrm{D}_{2} \mathrm{O}(\mathrm{g})$ and the metal hydroxides. The volatile products are then characterized with the mass spectrometer. There are pressure limitations on this techniques as the ionizer and detector of the instrument cannot tolerate $\mathrm{P}\left(\mathrm{H}_{2} \mathrm{O}\right)$ greater than $\sim 10^{-5}$ bar.

A free jet-sampling mass spectrometer (FJSMS) can directly sample a 1 bar chemical process in an oxidizing environment. This type of instrument has been described in detail elsewhere [28-29] and the principle will be briefly summarized here. The system consists of a series of differentially pumped vacuum chambers. In our system, the reaction occurs 
in a tube furnace adjacent to a small orifice in a Pt-Rh sampling cone. The gas species enter the orifice and undergo a free jet expansion. An abrupt transition to molecular flow occurs and the molecular beam is directed to a mass spectrometer. The actual expansion process is quite complex and dependent on the mass of the vapor species. We use a quadrupole mass spectrometer, which further introduces mass discrimination effects. Hence conversion of ion intensities to absolute pressures cannot be easily done. We use our instrument only for qualitative determinations of the amounts of volatile hydroxides and oxy-hydroxides [30].

The most valuable quantitative technique for obtaining thermodynamic data on hydroxides is the transpiration method [31]. A carrier gas entrains an equilibrium vapor and transports it to a low temperature portion of the system where it condenses. This amount of condensate is accurately determined by an appropriate analytical technique. From the amount of condensate and assuming the vapor specie is known, the vapor pressure of that species can be calculated. This vapor pressure can be calculated as a function of water vapor pressure to confirm the species' identity and as a function of temperature to obtain thermodynamic data. Flow rates are set to avoid surface reaction kinetic limitations and gas phase diffusion limitations on the reaction rate. Among the first studies of hydroxides with this technique are those of Glemser and colleagues [3234]. Belton and colleagues [35-37] have also used transpiration to study transition metal hydroxides. More recently Hashimoto [38] has used the transpiration method to study $\mathrm{Ca}, \mathrm{Si}$, and $\mathrm{Al}$ hydroxides. He uses a $\mathrm{Pt} / \mathrm{Rh}$ transpiration cell.

Our transpiration apparatus [39] is shown schematically in Figure 2. We also use a Pt/Rh transpiration cell. We use a peristaltic pump to inject water into the gas stream. An argon blanket gas flows in the region between the furnace tube and the transpiration cell. The blanket gas is monitored with a residual gas analyzer to detect any leaks in the system.

Metal hydroxides have also been studied in hydrogen-oxygen flames using spectroscopic techniques. The metals often form mono-hydroxides such as $\mathrm{CuOH}, \mathrm{GaOH}$, and $\mathrm{InOH}$ 
[40-41]. These studies yield data over a wide range of temperature, but proper identification of spectral lines may be difficult.

Thermal functions for many metal hydroxides have been estimated treating the hydroxyl group as a pseudo halide [2, 23, 42-46]. Various correlations have been established between fluoride or chloride and corresponding hydroxide bond strengths. Vibrational frequencies and molecular shapes for hydroxides have also been taken from fluorides and chlorides.

$A b$ initio methods of quantum chemistry should yield more accurate thermal functions for hydroxides [47, 48]. Baushlicher et al. [47] have calculated dissociation energies and shapes of the alkali and alkaline-earth mono-hydroxides. They conclude that the more ionic hydroxides are linear and the more covalent hydroxides are bent. This is consistent with experimental data $[49,50]$. Allendorf et al. [48] use ab initio methods to calculate thermal functions for a variety of $\mathrm{Si}-\mathrm{O}-\mathrm{H}$ species. Their results will be compared to our experimental data in a later section.

\section{Review of Thermodynamics of Metal Hydroxides}

There are only a few reviews in the literature on the thermodynamics of volatile metal hydroxides $[1,2,42,51,52]$. The authors of these reviews look for periodic trends in thermodynamic stabilities; however given the limited experimental data it is difficult to find these trends. Some element groups in the periodic table do lead to highly stable volatile hydroxides and/or oxy-hydroxides.

Table I presents available experimental enthalpies $\left(\Delta_{\mathrm{r}} \mathrm{H}^{\circ}(298)\right)$ and entropies $\left(\Delta_{\mathrm{r}} \mathrm{S}^{\circ}(298)\right)$ for a series of hydroxide formation reactions from the condensed phase oxide, i.e. reaction (2). The condensed phase oxide with the highest metal oxidation state was selected, e.g. $\mathrm{Fe}_{2} \mathrm{O}_{3}$ for $\mathrm{Fe}$. Only data for experimentally observed gaseous hydroxide or oxy-hydroxide species are listed in the table. When the data appeared to be estimated, 
they are not listed. Note that for the Group I hydroxides, with the exception of $\operatorname{Li}(\mathrm{OH})(\mathrm{g})$ and $\mathrm{Li}(\mathrm{OH})_{2}(\mathrm{~g})$ [21], form by direct vaporization only (reaction (1)) and this reaction is given.

For all the reactions, a more favorable change in free energy is attained by a lower $\Delta_{\mathrm{r}} \mathrm{H}^{\mathrm{o}}(298)$ and a higher $\Delta_{\mathrm{r}} \mathrm{S}^{\mathrm{o}}(298)$. For this approximation, we assume a constant $\Delta_{\mathrm{r}} \mathrm{H}^{\mathrm{o}}$ and $\Delta_{\mathrm{r}} S^{\circ}$ with temperature. Note also that at higher temperatures the $\mathrm{T} \Delta_{\mathrm{r}} S^{\circ}$ term in free energy becomes more important and the particular reaction will be more important [2].

Table I also gives an estimate of metal-hydroxide group bond energies at $298.15 \mathrm{~K}$ from these experimental data. These bond energies were estimated [5] from:

$$
\begin{aligned}
& \mathrm{MOH}(\mathrm{g})=\mathrm{M}(\mathrm{g})+\mathrm{OH}(\mathrm{g}) \\
& \mathrm{M}(\mathrm{OH})_{2}(\mathrm{~g})=\mathrm{M}(\mathrm{g})+2 \mathrm{OH}(\mathrm{g}) \\
& \mathrm{MO}(\mathrm{OH})_{2}(\mathrm{~g})=\mathrm{MO}(\mathrm{g})+2 \mathrm{OH}(\mathrm{g}) \\
& \mathrm{MO}_{2}(\mathrm{OH})_{2}(\mathrm{~g})=\mathrm{MO}_{2}(\mathrm{~g})+2 \mathrm{OH}(\mathrm{g})
\end{aligned}
$$

The bond energies are useful to compare the strengths of the metal-hydroxide group bond for the various species.

For the data taken from the JANAF [45] and IVTAN [46] tables, the $\Delta_{\mathrm{r}} \mathrm{H}(298), \Delta_{\mathrm{r}} \mathrm{S}(298)$ and bond energy could be readily calculated. For the data taken from other sources, these quantities were calculated from the vapor pressures and partition functions. Vibrational frequencies, interatomic distances, and bond angles were taken from the sources cited.

In surveying the literature, we found some controversy in the shape of the metal-oxygenhydrogen bond. Consider first the simple mono-hydroxides. As noted, ab initio calculations [47] indicate that metal mono-hydroxides with ionic metal/hydroxide bonds are linear; whereas the metal/hydroxide bond is bent if it has a larger degree of covalent character. This $a b$ initio study [47] shows that all alkali and alkaline-earth monohydroxides are linear, except for $\mathrm{BeOH}$, which has a larger degree of covalency. 
Recent spectroscopic studies on $\mathrm{CuOH}$ and $\mathrm{AgOH}$ indicate a bent structure [50]. It is likely that all the transition elements form hydroxides with bent $\mathrm{M}-\mathrm{O}-\mathrm{H}$ structures. Ebbinghaus [44] assumes a bent structure for $\mathrm{Cr}-\mathrm{O}-\mathrm{H}$ in all the various chromium hydroxides and oxy-hydroxides for which he estimates thermal functions. In our literature search, we found some calculations done for linear structures of transition metal hydroxides and some for bent structures. For these situations where there is some controversy about the shape of the molecule, we have done the 'third law' calculation for both a linear and bent molecule, using the spectroscopic data discussed above. The two different molecular shapes result in two different calculated moments of inertia, which in turn lead to different rotational partition functions. Compare the linear and bent molecules in Table I. Note that heat of reaction is generally increased about $20 \mathrm{~kJ} / \mathrm{mol}$, the entropy of reaction is increased about $20 \mathrm{~J} / \mathrm{mol}-\mathrm{K}$ and the calculated bond energy is decreased about $20 \mathrm{~kJ} / \mathrm{mol}$ in changing from a linear to a bent molecule.

The possibility of a bent M-O-H bond on the di-hydroxides is less well-studied. There does not seem to be experimental data on the shapes of any of these species. In general if the M-O-H bond is bent in the mono-hydroxide; it is assumed to be bent in the dihydroxide. The presence of an additional hydroxide group suggests an internal rotation-either free or hindered. Ebbinghaus [44] assumes the $\mathrm{Cr}(\mathrm{OH})_{2}(\mathrm{~g})$ has free internal rotations and the higher hydroxides have hindered rotations. So now the altered moments of inertia and internal rotations have a larger impact on the partition function. Note the large effect on the enthalpy, entropy, and bond energy for $\mathrm{Mn}(\mathrm{OH})_{2}(\mathrm{~g})$, shown in Table I.

This brief review has several findings:

1. The only complete data sets are for groups IA, IIA, VIA, and IIIB.

2. With the exception of the first row, the bond energies for groups IA and IIA are fairly constant.

3. For group IIB, the hydroxides become less stable with increasing atomic number. 
4. Group VIA tends to form highly stable oxy-hydroxides. Here with increasing atomic number they become less stable.

5. There are also several exceptionally stable hydroxides and oxy-hydroxides. These are $\mathrm{Be}(\mathrm{OH})_{2}, \mathrm{BO}(\mathrm{OH}), \mathrm{B}(\mathrm{OH})_{2}$ and the Group VIA oxy-hydroxides.

6. Theoretical evidence and spectroscopic evidence indicate that the monohydroxides with ionic bonding are linear; whereas the mono-hydroxides with more covalent bonding are bent. Recalculation of the partition functions for the transition metal hydroxides assuming a bent metal/hydroxide bond will yield a more accurate thermal functions.

\section{Experimental Study of the Si-O-H System}

In the last part of this paper, we discuss our recent experimental work on the $\mathrm{Si}-\mathrm{O}-\mathrm{H}$ system. We use both transpiration and free jet expansion mass spectrometry, as discussed in the experimental section. Transpiration studies were done over a range of temperatures and pressures. Thermodynamic quantities were derived from both the second and third law methods.

There are a number of possible reactions in this system [43]:

$$
\begin{aligned}
& \mathrm{SiO}_{2}(\mathrm{~s})+1 / 2 \mathrm{H}_{2} \mathrm{O}(\mathrm{g})=\mathrm{SiO}(\mathrm{OH})(\mathrm{g})+1 / 4 \mathrm{O}_{2}(\mathrm{~g}) \\
& \mathrm{SiO}_{2}(\mathrm{~s})+\mathrm{H}_{2} \mathrm{O}(\mathrm{g})=\mathrm{SiO}(\mathrm{OH})_{2}(\mathrm{~g}) \\
& \mathrm{SiO}_{2}(\mathrm{~s})+2 \mathrm{H}_{2} \mathrm{O}(\mathrm{g})=\mathrm{Si}(\mathrm{OH})_{4}(\mathrm{~g}) \\
& 2 \mathrm{SiO}_{2}(\mathrm{~s})+3 \mathrm{H}_{2} \mathrm{O}(\mathrm{g})=\mathrm{Si}_{2} \mathrm{O}(\mathrm{OH})_{6}(\mathrm{~g})
\end{aligned}
$$

There are two sets of calculated data for these species. One is based on treatment of the hydroxyl group as a pseudo-halide [43]; the other is based on ab initio methods [48].

These results are plotted as function of temperature in Figure 3. The vapor pressures of $\mathrm{Si}(\mathrm{OH})_{4}$ show reasonable agreement; however there is clear disagreement on the vapor pressures of $\mathrm{SiO}(\mathrm{OH})$ and $\mathrm{SiO}(\mathrm{OH})_{2}$.

As noted, Hashimoto [38] has done a precise transpiration study of the Si-O-H system from $1173-1773 \mathrm{~K}$. His pressure dependent experiments indicate that $\mathrm{Si}(\mathrm{OH})_{4}$ is the 
dominant vapor species. He derives second law enthalpies and entropies from his measurements. We did a transpiration and mass spectrometry study to look further at the identity of the vapor species and also obtain third law enthalpies, based on the ab initio thermal functions of Allendorf et al. [48].

Our transpiration apparatus has been described earlier in this paper. The deposits of $\mathrm{Si}$ containing species on the $\mathrm{Pt} / \mathrm{Rh}$ collection tube were dissolved in a solution of $4 \% \mathrm{HF}$ at $50^{\circ} \mathrm{C}$. The solution was then analyzed with plasma emission spectroscopy. The lower limit of detection was about $20 \mu \mathrm{g}$ of $\mathrm{Si}$. The amount of $\mathrm{Si}$ containing condensate was converted to vapor pressure by considering the flow rate of the argon carrier gas, water vapor, and the Si vapor species. Consider first the molar flow rate of $\mathrm{Ar}, Q_{A r}$, entering the furnace (position 1) before water is introduced:

$$
Q_{A r}=\frac{P_{1} f_{1}}{R T_{1}}
$$

Here $P$ is the pressure, $f$ is the volume flow rate, $R$ is the gas constant, and $T$ is the absolute temperature. The volume flow rate entering the reaction chamber (position 2 ) is given by

$f_{2}=\frac{T_{2}}{P_{2}} R\left[Q_{w}+Q_{A r}\right]$

Here $Q_{w}$ is the molar flow rate of water. The volume flow rate leaving the reaction chamber (position 3) is simply expression (12) with the addition of $Q_{S i}$. This is small in comparison to $Q_{w}+Q_{A r}$, so we can take $f_{3}=f_{2}$. Finally the pressure of Si species leaving the reaction chamber (position 3 ) is given by:

$\frac{P_{S i}}{P_{T}}=\frac{Q_{S i}}{Q_{A r}+Q_{w}+Q_{S i}} \quad$ or $\quad \frac{P_{S i}}{P_{T}}=\frac{Q_{S i} R T_{3}}{f_{3}}$

$Q_{S i}$ is calculated from the amount of $\mathrm{Si}$ in the deposit collected.

In these transpiration experiments the identity of the vapor species are best determined by the dependence of pressure of $\mathrm{Si}-\mathrm{O}-\mathrm{H}$ species on the partial pressure of water vapor. For the formation of $\mathrm{Si}(\mathrm{OH})_{4}$ according to reaction (10c) a plot of $\log \mathrm{P}(\mathrm{Si}-\mathrm{OH})$ vs $\log$ $\mathrm{P}\left(\mathrm{H}_{2} \mathrm{O}\right)$ should yield a slope of 2 . For the formation of $\mathrm{SiO}(\mathrm{OH})_{2}$ according to reaction (10b) such a plot should yield a slope of 1. The results are shown in Figure 4 for 1073, 
1273 , and $1473 \mathrm{~K}$. The lower temperatures have a slope close to 2; but the high temperature has a slope of 1.69 . Thus at lower temperatures, $\mathrm{Si}(\mathrm{OH})_{4}$ appears to be the dominant specie; whereas at higher temperatures a second specie, very likely $\mathrm{SiO}(\mathrm{OH})_{2}$, is also important. It can be shown that an exponent of 1.69 corresponds to 0.31 $\mathrm{SiO}(\mathrm{OH})_{2}(\mathrm{~g})$ and $0.69 \mathrm{Si}(\mathrm{OH})_{4}(\mathrm{~g})[39]$.

These results are consistent with studies in our free-jet expansion mass spectrometer. Hydroxides also behave like pseudo-halogens in mass spectrometer fragmentation processes. Thus a typically observed ion is formed by the removal of one hydroxyl group from the parent. The major ions were $\mathrm{Si}(\mathrm{OH})_{3}{ }^{+}$and $\mathrm{SiO}(\mathrm{OH})^{+}$, which correspond to $\mathrm{Si}(\mathrm{OH})_{4}$ and $\mathrm{SiO}(\mathrm{OH})_{2}$, respectively.

Having identified $\mathrm{Si}(\mathrm{OH})_{4}$ as the major specie to about $1373 \mathrm{~K}$, we can then obtain a second law heat and entropy from the van't Hoff equation:

$$
\ln K=\frac{-\Delta H^{o}}{R}\left(\frac{1}{T}\right)+\frac{\Delta S^{o}}{R} \quad \text { with } \quad K=\frac{P\left(\mathrm{Si}(\mathrm{OH})_{4}\right)}{\left[P\left(\mathrm{H}_{2} \mathrm{O}\right)\right]^{2}}
$$

The results are shown in Figure 5 and Table II. Values from the calculations of Allendorf et al. [48] and experimental measurements of Hashimoto [38] are shown for comparison and the agreement is very good.

The calculations of Allendorf et al. allow the derivation of the free energy function for a third law calculation of $\Delta_{\mathrm{r}} \mathrm{H}^{\mathrm{o}}(298)$. Allendorf's calculation leads to the $\mathrm{Si}(\mathrm{OH})_{4}$ structure with symmetry group $C_{1}$ and four hindered internal rotations. His numbers for the enthalpy of formation at $298.15 \mathrm{~K}$ and free energy of formation were fitted to a polynomial of IVTAN form [46]. This was combined with the IVTAN data for $\mathrm{Si}, \mathrm{O}_{2}$, $\mathrm{H}_{2}$ to yield the free energy function of $\mathrm{Si}(\mathrm{OH})_{4}$ :

$$
\begin{aligned}
& \text { FEF }\left(\mathrm{Si}(\mathrm{OH})_{4}\right)=-2234.21313+-662.11547 * \ln (T / 10000)+0.124 *(T / 10000)^{-2}+ \\
& -22.89238 *(T / 10000)^{-1}+7126.04925 *(T / 10000)+-24458.89172 *(T / 10000)^{2} \\
& +40760.17257 *(T / 10000)^{3}
\end{aligned}
$$

This was used with the standard third law equation to calculation an enthalpy of reaction for reaction (10c): 
$\Delta_{r} H^{o}(298)=\Delta G^{o}(T)-T \Delta\left(\frac{G^{o}(T)-H^{o}(298)}{T}\right)=R T \ln K_{p}-T \Delta\left(F E F^{o}(298)\right) \quad[16]$

Twenty nine data points from our transpiration study were used to calculate an enthalpy and the results are shown in Table II. The agreement with Allendorf's calculations is excellent.

\section{Summary and Conclusions}

Volatile metal hydroxides are important in a number of high temperature corrosion processes. Examples of these have been discussed. Thermodynamic data on these species are limited, in part due to the complexities of thermodynamic measurements in oxidizing environments. Gas leak Knudsen cell mass spectrometry, free-jet sampling mass spectrometry, transpiration, and $\mathrm{H}_{2} / \mathrm{O}_{2}$ flames are the commonly used experimental techniques. Theoretical predictions of thermodynamic quantities for these metal hydroxides and oxy-hydroxides have been made using the pseudo halogen behavior of the hydroxyl group. More recently, $a b$ initio methods have been applied to obtain thermodynamic quantities. An important result from the latter is that the ionic monohydroxides tend to have linear $\mathrm{M}-\mathrm{O}-\mathrm{H}$ bonding and the more covalent hydroxides tend to have bent $\mathrm{M}-\mathrm{O}-\mathrm{H}$ bonding.

Available experimental data on metal hydroxides have been discussed. From these data, enthalpies and entropies of formation from water vapor and the most stable oxide are calculated as well as metal/hydroxide bond energies. Although experimental data on many hydroxides are unavailable, some trends can be observed. With the exception of the first row, groups IA and IIA have fairly constant metal hydroxide bond energies. For group IIIB, the metal hydroxide bond energy decreases with increasing atomic number. There are also several exceptionally stable hydroxides and oxy-hydroxides. These are $\mathrm{Be}(\mathrm{OH})_{2}, \mathrm{BO}(\mathrm{OH}), \mathrm{B}(\mathrm{OH})_{2}$ and the Group VIA oxy-hydroxides.

Studies from our laboratories on the Si-O-H system are discussed. Transpiration and free-jet sampling mass spectrometry are used. It appears that $\mathrm{Si}(\mathrm{OH})_{4}$ is the dominant 
vapor specie to about $1373 \mathrm{~K}$; above that $\mathrm{SiO}(\mathrm{OH})_{2}$ may be important. A second law enthalpy and entropy and a third law enthalpy for the reaction of water vapor and $\mathrm{SiO}_{2}$ to form $\mathrm{Si}(\mathrm{OH})_{4}$ are reported. These compare favorably with theoretical calculations [48] and previous experimental data [38].

\section{Acknowledgements}

Helpful discussions with Drs. L. Gorokhov (Russian Academy of Sciences), M.

Allendorf (Sandia National Laboratories), M. Zehe (NASA Glenn) are very much appreciated. Thanks are also due to D. Simon and G. Blank (both of NASA Glenn) for the design and fabrication of the transpiration cell. 


\begin{tabular}{|c|c|c|c|c|c|c|}
\hline Group & Reaction & $\Delta_{r} H_{298}^{o} \mathrm{~kJ} / \mathrm{mol}$ & $\begin{array}{l}\Delta_{r} S_{298}^{o} \\
\mathrm{~J} / \mathrm{mol}-\mathrm{K}\end{array}$ & $\begin{array}{l}D_{298}^{o}(M-O H) \\
\mathrm{kJ} / \mathrm{mol}\end{array}$ & $\begin{array}{l}\text { Geometry of } \\
\text { M-OH Bond }\end{array}$ & Reference \\
\hline \multirow[t]{5}{*}{ IA } & $\mathrm{Li}_{2} \mathrm{O}(\mathrm{s})+\mathrm{H}_{2} \mathrm{O}(\mathrm{g})=2 \mathrm{Li}(\mathrm{OH})(\mathrm{g})$ & 186 & 97 & 433 & Linear & JANAF [45] \\
\hline & $\mathrm{NaOH}(\mathrm{s})=\mathrm{NaOH}(\mathrm{g})$ & 228 & 163 & 344 & Linear & JANAF [45] \\
\hline & $\mathrm{KOH}(\mathrm{s})=\mathrm{KOH}(\mathrm{g})$ & 192 & 157 & 360 & Linear & JANAF [45] \\
\hline & $\mathrm{RbOH}(\mathrm{s})=\mathrm{RbOH}(\mathrm{g})$ & 177 & 156 & 361 & Linear & IVTAN [46] \\
\hline & $\mathrm{CsOH}(\mathrm{s})=\mathrm{CsOH}(\mathrm{g})$ & 157 & 156 & 374 & Linear & JANAF [45] \\
\hline \multirow[t]{10}{*}{ IIA } & $\mathrm{BeO}(\mathrm{s})+1 / 2 \mathrm{H}_{2} \mathrm{O}(\mathrm{g})=\mathrm{Be}(\mathrm{OH})(\mathrm{g})+1 / 4 \mathrm{O}_{2}(\mathrm{~g})$ & 614 & 153 & 477 & See text & JANAF [45] \\
\hline & $\mathrm{BeO}(\mathrm{s})+\mathrm{H}_{2} \mathrm{O}(\mathrm{g})=\mathrm{Be}(\mathrm{OH})_{2}(\mathrm{~g})$ & 174 & 31 & 539 & See text & JANAF [45] \\
\hline & $\mathrm{MgO}(\mathrm{s})+1 / 2 \mathrm{H}_{2} \mathrm{O}(\mathrm{g})=\mathrm{Mg}(\mathrm{OH})(\mathrm{g})+1 / 4 \mathrm{O}_{2}(\mathrm{~g})$ & 557 & 156 & 350 & Linear & JANAF [45] \\
\hline & $\mathrm{MgO}(\mathrm{s})+\mathrm{H}_{2} \mathrm{O}(\mathrm{g})=\mathrm{Mg}(\mathrm{OH})_{2}(\mathrm{~g})$ & 271 & 52 & 399 & Linear & JANAF [45] \\
\hline & $\mathrm{CaO}(\mathrm{s})+1 / 2 \mathrm{H}_{2} \mathrm{O}(\mathrm{g})=\mathrm{Ca}(\mathrm{OH})(\mathrm{g})+1 / 4 \mathrm{O}_{2}(\mathrm{~g})$ & 562 & 154 & 410 & Linear & \begin{tabular}{|l|} 
JANAF [45] \\
\end{tabular} \\
\hline & $\mathrm{CaO}(\mathrm{s})+\mathrm{H}_{2} \mathrm{O}(\mathrm{g})=\mathrm{Ca}(\mathrm{OH})_{2}(\mathrm{~g})$ & 266 & 59 & 433 & Linear & JANAF [45] \\
\hline & $\mathrm{SrO}(\mathrm{s})+1 / 2 \mathrm{H}_{2} \mathrm{O}(\mathrm{g})=\mathrm{Sr}(\mathrm{OH})(\mathrm{g})+1 / 4 \mathrm{O}_{2}(\mathrm{~g})$ & 507 & 148 & 408 & Linear & JANAF [45] \\
\hline & $\mathrm{SrO}(\mathrm{s})+\mathrm{H}_{2} \mathrm{O}(\mathrm{g})=\mathrm{Sr}(\mathrm{OH})_{2}(\mathrm{~g})$ & 238 & 61 & 434 & Linear & JANAF [45] \\
\hline & $\mathrm{BaO}(\mathrm{s})+1 / 2 \mathrm{H}_{2} \mathrm{O}(\mathrm{g})=\mathrm{Ba}(\mathrm{OH})(\mathrm{g})+1 / 4 \mathrm{O}_{2}(\mathrm{~g})$ & 443 & 138 & 444 & Linear & \begin{tabular}{|l|} 
JANAF [45] \\
\end{tabular} \\
\hline & $\mathrm{BaO}(\mathrm{s})+\mathrm{H}_{2} \mathrm{O}(\mathrm{g})=\mathrm{Ba}(\mathrm{OH})_{2}(\mathrm{~g})$ & 163 & 54 & 442 & Linear & JANAF [45] \\
\hline \multirow[t]{5}{*}{ VIA } & $1 / 2 \mathrm{Cr}_{2} \mathrm{O}_{3}(\mathrm{~s})+1 / 2 \mathrm{H}_{2} \mathrm{O}(\mathrm{g})=\mathrm{CrOH}(\mathrm{g})+1 / 2 \mathrm{O}_{2}(\mathrm{~g})$ & $\begin{array}{l}747 \\
770\end{array}$ & $\begin{array}{l}213 \\
227 \\
\end{array}$ & $\begin{array}{l}380 \\
358\end{array}$ & $\begin{array}{l}\text { Linear } \\
\text { Bent }\end{array}$ & $\begin{array}{l}\text { Gorokhov et al. } \\
{[23]}\end{array}$ \\
\hline & $\begin{array}{l}1 / 2 \mathrm{Cr}_{2} \mathrm{O}_{3}(\mathrm{~s})+\mathrm{H}_{2} \mathrm{O}(\mathrm{g})+3 / 4 \mathrm{O}_{2}(\mathrm{~g})= \\
\mathrm{CrO}_{2}(\mathrm{OH})_{2}(\mathrm{~g})\end{array}$ & 61 & -26 & 375 & Bent & $\begin{array}{l}\text { Ebbinghaus } \\
{[44]}\end{array}$ \\
\hline & $\mathrm{MoO}_{3}(\mathrm{~s})+\mathrm{H}_{2} \mathrm{O}(\mathrm{g})=\mathrm{MoO}_{2}(\mathrm{OH})_{2}(\mathrm{~g})$ & 135 & 89 & 460 & & JANAF [45] \\
\hline & $\mathrm{WO}_{3}(\mathrm{~s})+\mathrm{H}_{2} \mathrm{O}(\mathrm{g})=\mathrm{WO}_{2}(\mathrm{OH})_{2}(\mathrm{~g})$ & 530 & 87 & 530 & & JANAF [45] \\
\hline & & & & & & \\
\hline
\end{tabular}




\begin{tabular}{|c|c|c|c|c|c|c|}
\hline VIIA & $\mathrm{MnO}_{2}(\mathrm{~s})+1 / 2 \mathrm{H}_{2} \mathrm{O}(\mathrm{g})=\mathrm{Mn}(\mathrm{OH})(\mathrm{g})+3 / 4 \mathrm{O}_{2}(\mathrm{~g})$ & $\begin{array}{l}641.54 \\
663.96 \\
\end{array}$ & $\begin{array}{l}253.71 \\
268.33\end{array}$ & $\begin{array}{l}322.42 \\
300.01\end{array}$ & $\begin{array}{l}\text { Linear } \\
\text { Bent }\end{array}$ & $\begin{array}{l}\text { Hildenbrand and } \\
\text { Lau [24] }\end{array}$ \\
\hline & $\mathrm{MnO}_{2}(\mathrm{~s})+1 / 2 \mathrm{H}_{2} \mathrm{O}(\mathrm{g})=\mathrm{MnO}(\mathrm{OH})(\mathrm{g})+1 / 4 \mathrm{O}_{2}(\mathrm{~g})$ & $\begin{array}{l}469.87 \\
469.18 \\
\end{array}$ & $\begin{array}{l}205.79 \\
218.74 \\
\end{array}$ & $\begin{array}{l}372.21 \\
372.89 \\
\end{array}$ & $\begin{array}{l}\text { Linear } \\
\text { Bent }\end{array}$ & $\begin{array}{l}\text { Hildenbrand and } \\
\text { Lau [24] }\end{array}$ \\
\hline & $\mathrm{MnO}_{2}(\mathrm{~s})+\mathrm{H}_{2} \mathrm{O}(\mathrm{g})=\mathrm{Mn}(\mathrm{OH})_{2}(\mathrm{~g})+1 / 2 \mathrm{O}_{2}(\mathrm{~g})$ & $\begin{array}{l}362.82 \\
442.08 \\
\end{array}$ & $\begin{array}{l}289.04 \\
310.63 \\
\end{array}$ & $\begin{array}{l}361.03 \\
322.38 \\
\end{array}$ & $\begin{array}{l}\text { Linear } \\
\text { Bent }\end{array}$ & $\begin{array}{l}\text { Hildenbrand and } \\
\text { Lau [24] }\end{array}$ \\
\hline \multirow[t]{2}{*}{ VIII } & $1 / 2 \mathrm{Fe}_{2} \mathrm{O}_{3}(\mathrm{~s})+1 / 2 \mathrm{H}_{2} \mathrm{O}(\mathrm{g})=\mathrm{Fe}(\mathrm{OH})(\mathrm{g})+1 / 2 \mathrm{O}_{2}(\mathrm{~g})$ & $\begin{array}{l}652.80 \\
668.79 \\
\end{array}$ & $\begin{array}{l}213.37 \\
228.59 \\
\end{array}$ & $\begin{array}{l}334.31 \\
318.32\end{array}$ & $\begin{array}{l}\text { Linear } \\
\text { Bent }\end{array}$ & Murad [22] \\
\hline & $1 / 2 \mathrm{Fe}_{2} \mathrm{O}_{3}(\mathrm{~s})+\mathrm{H}_{2} \mathrm{O}(\mathrm{g})=\mathrm{Fe}(\mathrm{OH})_{2}(\mathrm{~g})+1 / 4 \mathrm{O}_{2}(\mathrm{~g})$ & 324.04 & 153.13 & 439.22 & Bent & $\begin{array}{l}\text { Belton and } \\
\text { Richardson [35] } \\
\text { JANAF [45] }\end{array}$ \\
\hline IB & $\mathrm{CuO}(\mathrm{s})+1 / 2 \mathrm{H}_{2} \mathrm{O}(\mathrm{g})=\mathrm{Cu}(\mathrm{OH})(\mathrm{g})+1 / 4 \mathrm{O}_{2}(\mathrm{~g})$ & $\begin{array}{l}400.02 \\
429.47 \\
\end{array}$ & $\begin{array}{l}145.49 \\
160.99\end{array}$ & $\begin{array}{l}259.84 \\
230.39 \\
\end{array}$ & $\begin{array}{l}\text { Linear } \\
\text { Bent }\end{array}$ & $\begin{array}{l}\text { Belyaev et al. } \\
{[40]}\end{array}$ \\
\hline IIB & $\mathrm{ZnO}(\mathrm{s})+\mathrm{H}_{2} \mathrm{O}(\mathrm{g})=\mathrm{Zn}(\mathrm{OH})_{2}(\mathrm{~g})$ & 201.39 & 54.89 & 300 & Bent & $\begin{array}{l}\text { Glemser et al. } \\
{[32]}\end{array}$ \\
\hline \multirow[t]{7}{*}{ IIIB } & $1 / 2 \mathrm{~B}_{2} \mathrm{O}_{3}(\mathrm{~s})+1 / 2 \mathrm{H}_{2} \mathrm{O}(\mathrm{g})=\mathrm{BO}(\mathrm{OH})(\mathrm{g})$ & 196 & 118 & 600 & & JANAF [45] \\
\hline & $1 / 2 \mathrm{~B}_{2} \mathrm{O}_{3}(\mathrm{~s})+\mathrm{H}_{2} \mathrm{O}(\mathrm{g})=\mathrm{B}(\mathrm{OH})_{2}(\mathrm{~g})+1 / 4 \mathrm{O}_{2}(\mathrm{~g})$ & 401 & 84 & 557 & & JANAF [45] \\
\hline & $1 / 2 \mathrm{~B}_{2} \mathrm{O}_{3}(\mathrm{~s})+3 / 2 \mathrm{H}_{2} \mathrm{O}(\mathrm{g})=\mathrm{B}(\mathrm{OH})_{3}(\mathrm{~g})$ & 6.4 & -15 & 556 & & JANAF [45] \\
\hline & $1 / 2 \mathrm{Al}_{2} \mathrm{O}_{3}(\mathrm{~s})+1 / 2 \mathrm{H}_{2} \mathrm{O}(\mathrm{g})=\mathrm{Al}(\mathrm{OH})(\mathrm{g})+1 / 2 \mathrm{O}_{2}(\mathrm{~g})$ & 779 & 199 & 549 & & IVTAN [45] \\
\hline & $1 / 2 \mathrm{Al}_{2} \mathrm{O}_{3}(\mathrm{~s})+1 / 2 \mathrm{H}_{2} \mathrm{O}(\mathrm{g})=\mathrm{AlO}(\mathrm{OH})(\mathrm{g})$ & 498 & 134 & 566 & & JANAF [45] \\
\hline & $1 / 2 \mathrm{Al}_{2} \mathrm{O}_{3}(\mathrm{~s})+\mathrm{H}_{2} \mathrm{O}(\mathrm{g})=\mathrm{Al}(\mathrm{OH})_{2}(\mathrm{~g})+1 / 4 \mathrm{O}_{2}(\mathrm{~g})$ & 572 & 121 & 458 & & IVTAN [46] \\
\hline & $1 / 2 \mathrm{Al}_{2} \mathrm{O}_{3}(\mathrm{~s})+3 / 2 \mathrm{H}_{2} \mathrm{O}(\mathrm{g})=\mathrm{Al}(\mathrm{OH})_{3}(\mathrm{~g})$ & 188 & -7.3 & 487 & & $\begin{array}{l}\text { Hashimoto/ } \\
\text { IVTAN }[38,46]\end{array}$ \\
\hline
\end{tabular}




\begin{tabular}{|c|c|c|c|c|c|c|}
\hline & $1 / 2 \mathrm{Ga}_{2} \mathrm{O}_{3}(\mathrm{~s})+1 / 2 \mathrm{H}_{2} \mathrm{O}(\mathrm{g})=\mathrm{Ga}(\mathrm{OH})(\mathrm{g})+1 / 2 \mathrm{O}_{2}(\mathrm{~g})$ & \begin{tabular}{|l|}
549.62 \\
569.74 \\
\end{tabular} & $\begin{array}{r}210.65 \\
223.58 \\
\end{array}$ & $\begin{array}{l}428.15 \\
408.02 \\
\end{array}$ & $\begin{array}{l}\text { Linear } \\
\text { Bent } \\
\end{array}$ & $\begin{array}{l}\text { Kelly and Padley } \\
{[41]}\end{array}$ \\
\hline & $1 / 2 \operatorname{In}_{2} \mathrm{O}_{3}(\mathrm{~s})+1 / 2 \mathrm{H}_{2} \mathrm{O}(\mathrm{g})=\mathrm{In}(\mathrm{OH})(\mathrm{g})+1 / 2 \mathrm{O}_{2}(\mathrm{~g})$ & \begin{tabular}{|l|}
493.92 \\
513.11 \\
\end{tabular} & \begin{tabular}{|l|}
215.43 \\
228.04 \\
\end{tabular} & $\begin{array}{l}368.54 \\
349.36 \\
\end{array}$ & $\begin{array}{l}\text { Linear } \\
\text { Bent }\end{array}$ & $\begin{array}{l}\text { Kelly and Padley } \\
{[41]}\end{array}$ \\
\hline \multirow[t]{3}{*}{ IVB } & $\mathrm{SiO}_{2}(\mathrm{~s})+1 / 2 \mathrm{H}_{2} \mathrm{O}(\mathrm{g})=\mathrm{SiO}(\mathrm{OH})(\mathrm{g})+1 / 4 \mathrm{O}_{2}(\mathrm{~g})$ & \begin{tabular}{|l|}
675.12 \\
718.12 \\
\end{tabular} & \begin{tabular}{|l|}
190.04 \\
187.62 \\
\end{tabular} & $\begin{array}{l}297 \\
254 \\
\end{array}$ & $\begin{array}{l}\text { Linear } \\
\text { Bent } \\
\end{array}$ & $\begin{array}{l}\text { Hildenbrand and } \\
\text { Lau }[25,26]\end{array}$ \\
\hline & $\mathrm{SiO}_{2}(\mathrm{~s})+\mathrm{H}_{2} \mathrm{O}(\mathrm{g})=\mathrm{SiO}(\mathrm{OH})_{2}(\mathrm{~g})$ & \begin{tabular}{|l|}
260.42 \\
316.78 \\
\end{tabular} & $\begin{array}{l}61.62 \\
64.46 \\
\end{array}$ & \begin{tabular}{|l|}
435.9 \\
408 \\
\end{tabular} & $\begin{array}{l}\text { Linear } \\
\text { Bent }\end{array}$ & $\begin{array}{l}\text { Hildenbrand and } \\
\text { Lau }[25,26]\end{array}$ \\
\hline & $\mathrm{SiO}_{2}(\mathrm{~s})+2 \mathrm{H}_{2} \mathrm{O}(\mathrm{g})=\mathrm{Si}(\mathrm{OH})_{4}(\mathrm{~g})$ & 55.30 & -76.18 & 486.61 & Bent & This study \\
\hline
\end{tabular}

Table I. Thermodynamic data on metal hydroxides. 


\begin{tabular}{|l|l|l|l|}
\hline Study & $\mathrm{T}(\mathrm{K})$ & $\Delta_{\mathrm{r}} \mathrm{H}(\mathrm{kJ} / \mathrm{mol})$ & $\Delta_{\mathrm{r}} \mathrm{S}(\mathrm{J} / \mathrm{mol}-\mathrm{K})$ \\
\hline Hashimoto-Second Law & 1600 & $56.7 \pm 1.7$ & $-66.2 \pm 1.0$ \\
\hline Allendorf-Second Law & 1200 & 57.02 & -64.8 \\
\hline This Study & 1200 & $54.5 \pm 2.8$ & $-67.6 \pm 2.2$ \\
\hline Allendorf & 298.15 & 55.3 & \\
\hline Krikorian & 298.15 & 56.5 & \\
\hline This Study-Third Law & 298.15 & $58.4 \pm 3.6$ & \\
\hline
\end{tabular}

Table II. Enthalpies and entropies for the reaction $\mathrm{SiO}_{2}$ (cristobalite) $+2 \mathrm{H}_{2} \mathrm{O}(\mathrm{g})=$ $\mathrm{Si}(\mathrm{OH})_{4}(\mathrm{~g})$. 


\section{References:}

1. O. Glemser and H. G. Wendlandt, in H. J. Emeléus and A. G. Sharpe (Eds.), Advan. Inorg. Chem. Radiochem. Vol. 5, 1963, pp. 215-54.

2. J. W. Hastie, High Temperature Vapors Science and Technology, Ch 2 and 5, Academic Press, New York, 1975.

3. N. S. Jacobson, Corrosion of Silicon-Based Ceramics in Combustion Environments, J. Am. Ceram. Soc. 76 (1993), 3-28.

4. I. Zaplatynsky, Volatilization of Oxides During Oxidation of Some Superalloys at $1200^{\circ} \mathrm{C}$, Oxid. Met. 11 (1977), 289-305.

5. O. H. Krikorian, Predictive calculations of volatilities of metals and oxides in steam-containing environments, H. Temp-H. Press 14 (1982), 387-97.

6. H. C. Graham and H. H. Davis, Oxidation/Vaporization Kinetics of $\mathrm{Cr}_{2} \mathrm{O}_{3}, \mathrm{~J}$. Am. Ceram. Soc. 54 (1971), 89-93.

7. C. E. Lowell and W. A. Sanders, Mach 1 Oxidation of Thoriated Nickel Chromium at $1204^{\circ} \mathrm{C}\left(2200^{\circ} \mathrm{F}\right)$, NASA Technical Note (1971), TN D-6562.

8. F. J. Kohl and C. A. Stearns, Vaporization of Chromium Oxides from Surface of TD-NiCr Under Oxidizing Conditions, NASA Technical Memorandum (1970) TM X-52879.

9. G. C. Fryburg, R. A. Miller, F. J. Kohl, and C. A. Stearns, Volatile Products in the Corrosion of $\mathrm{Cr}, \mathrm{Mo}, \mathrm{Ti}$, and Four Superalloys Exposed to $\mathrm{O}_{2}$ Containing $\mathrm{H}_{2} \mathrm{O}$ and Gaseous NaCl, J. Electrochem. Soc. 124 (1977), 1738-43.

10. G. Wahl and P. Batzies, Evaporation of Molybdenum in Vacuum, in $\mathrm{O}_{2-}^{-}$, and in $\mathrm{H}_{2} \mathrm{O}$-Atmospheres, in IEEE Conference Record of 1970 Thermionic Conversion Specialist Conference, Miami Beach, FL, IEEE, New York, pp. 119-21.

11. R. L. Fleischer, High-Temperature, High-Strength Materials-An Overview, J. Met. (Dec 1985), 16-20.

12. J. Buchanan and J. A. Little, Glass sealants for carbon-carbon composites, J. Mat. Sci. 28 (1993), 2324-2330.

13. N. S. Jacobson, G. N. Morscher, D. R. Bryant, and R. E. Tressler, HighTemperature Oxidation of Boron Nitride: II, Boron Nitride Layers in Composites, J. Am. Ceram. Soc. 82 (1999), 1473-82. 
14. E. J. Opila and R. E. Hann, Paralinear Oxidation of CVD SiC in Water Vapor, J. Am. Ceram. Soc. 80 (1997), 197-205.

15. R. C. Robinson and J. L. Smialek, $\mathrm{SiC}$ Recession Caused by $\mathrm{SiO}_{2}$ Scale Volatility under Combustion Conditions: Part I, Experimental Results and Empirical Model, J. Am. Ceram. Soc. 82 (1999), 1817-25.

16. E. J. Opila, J. L. Smialek, R. C. Robinson, D. S. Fox, and N. S. Jacobson, SiC Recession Caused by $\mathrm{SiO}_{2}$ Scale Volatility under Combustion Conditions: Part II, Thermodynamics and Gaseous-Diffusion Model, J. Am. Ceram. Soc. 82 (1999), 1826-34.

17. W.-P. Tai, T. Watanabe, and N. S. Jacobson, High-Temperature Stability of Alumina in Argon and Argon/Water-Vapor Environments, J. Am. Ceram. Soc. 82 (1999), 245-48.

18. Y. Etori, T. Hisamatsu, I. Yuri, Y. Yasutomi, T. Machida, and K. Wada, Oxidation Behavior of Ceramics for Gas Turbines in Combustion Gas Flow at $1500^{\circ} \mathrm{C}$, International Gas Turbine and Aeroengine Congress and Exhibition, Orlando, FL, June 2-5, 1997, Paper 97-GT-355.

19. I. Yuri and T. Hisamatsu, Recession Rate Prediction for Ceramic Materials in Combustion Gas Flow, Proceedings of ASME TURBO EXPO 2003, June 1619, Atlanta, GA, Paper GT2003-38886.

20. D. J. Meschi, W. A. Chupka, and J. Berkowitz, Heterogeneous Reactions Studied by Mass Spectrometry. I. Reactions of $\mathrm{B}_{2} \mathrm{O}_{3}(\mathrm{~s})$ with $\mathrm{H}_{2} \mathrm{O}(\mathrm{g})$, J. Chem. Phys. 33 (1960), 530-33.

21. J. A. Berkowitz, D. J. Meschi, and W. A. Chupka, Heterogeneous Reactions Studied by Mass Spectrometry. II. Reaction of $\mathrm{Li}_{2} \mathrm{O}(\mathrm{s})$ with $\mathrm{H}_{2} \mathrm{O}(\mathrm{g})$, J. Chem. Phys. 33 (1960), 533-40.

22. E. Murad, "Thermochemical properties of gaseous $\mathrm{FeO}$ and $\mathrm{FeOH}$," J. Chem. Phys. 73 (1980), 1381-85.

23. L. N. Gorokhov, J. I. Milushin, and A. M. Emelyanov, Knudsen Effusion Mass Spectmetric Determination of Metal Hydroxide Stabilities, H. Temp. Sci. 26 (1990), 395-403.

24. D. L. Hildenbrand and K. H. Lau, Thermochemistry of gaseous manganese oxides and hydroxides, J. Chem. Phys. 1000 (1994), 8377-80.

25. D. L. Hildenbrand and K. H. Lau, Thermochemistry of gaseous $\mathrm{SiO}(\mathrm{OH})$, $\mathrm{SiO}(\mathrm{OH})_{2}$, and $\mathrm{SiO}_{2}$, J. Chem. Phys. 101 (1994), 6076-79. 
26. D. L. Hildenbrand and K. H. Lau, Comment on "Thermochemistry of gaseous $\mathrm{SiO}(\mathrm{OH}), \mathrm{SiO}(\mathrm{OH})_{2}$, and $\mathrm{SiO}_{2}$," [J. Chem. Phys. 101, 6076 1994], J. Chem. Phys. 108 (1998), 6535.

27. M. Farber, R. D. Srivastava, M. A. Frisch and S. P. Harris, Mass Spectrometer Studies of $\mathrm{Al}+\mathrm{H}_{2} \mathrm{O}$ Reactions in Effusion Cells and in Atmospheric $\mathrm{H}_{2}+\mathrm{O}_{2}$ Flames, in High Temperature Studies in Chemistry, Faraday Symposia of the Chemical Society No. 8, 1973, pp. 121-130.

28. C. A. Stearns, F. J. Kohl, G. C. Fryburg, and R. A. Miller in J. W. Hastie [Ed.] Characterization of High Temperature Vapors and Gases, NBS Special Publication No. 561, National Bureau of Standards, Washington, D. C., 1978, pp. 303-55.

29. Applications of Free-Jet, Molecular Beam, Mass Spectrometric Sampling Proceedings, Estes Park, CO, October 11-14, 1994, NREL-CP_433-7748.

30. E. J. Opila, D. S. Fox, and N. S. Jacobson, "Mass Spectrometric Identification of Si-O-H(g) Species from the Reaction of Silica with Water Vapor at Atmospheric Pressure," J. Am. Ceram. Soc. 80 (1997), 1009-12.

31. U. Merten and W. E. Bell, in J. L. Margrave [Ed.], The Characterization of High Temperature Vapors, J. Wiley and Sons, Inc., New York, 1967. pp. 91-114.

32. O. Glemser, H. G. Völz, and B. Meyer, Gasförmge Hydroxyde. II. Über gasförmiges Zinkhydroxyd, Z. anorg. allgem. chem. 192 (1957), 311-24.

33. O. Glemser and R. V. Haeseler, Über gasförmiges Hydroxide des Molybdäns und Wolframs, Z. anorg. allgem. chem. 316 (1962), 169-81.

34. O. Glemser and A. Müller, Über ein gasförmiges Hydroxid des Chroms, Z. anorg. allgem. chem. 334, (1964) 150-54.

35. G. R. Belton and F. D. Richardson, A Volatile Iron Hydroxide, Trans. Far. Soc. 58 (1962), 1562-72.

36. G. R. Belton and R. L. McCarron, The Volatilization of Tungsten in the Presence of Water Vapor, J. Phys. Chem. 68 (1964), 1852-56.

37. Y-W. Kim and G. R. Belton, "The Thermodynamics of Volatilization of Chromic Oxide: Part I. The Species $\mathrm{CrO}_{3}$ and $\mathrm{CrO}_{2} \mathrm{OH}$," Met. Trans. 5 (1974), 1811-16. 
38. A. Hashimoto, "The effect of $\mathrm{H}_{2} \mathrm{O}$ gas on volatilities of planet-forming major elements: I. Experimental determination of thermodynamic properties of $\mathrm{Ca}$-, $\mathrm{Al}-$, and Si-hydroxide gas molecules and its application to the solar nebula," Geochim. Cosmochim. Acta, 56 (1992), 511-32.

39. E. Copland, D. Myers, E. J. Opila, and N. S. Jacobson, in M. McNallan and E. Opila [Eds.] High Temperature Corrosion and Materials Chemistry III, Proceedings of the International Symposium, The Electrochemical Society, Pennington, NJ, 2001, pp. 253-61.

40. V. N. Belyaev, N. L. Lebedeva, K. S. Krasnov, and L. V. Gurvich, Computation of copper oxide and hydroxide dissociation energy by the flame spectrophotometry method, Izvestiya vuzov. Khimiya i khim. tekhnol. 21 (1978), 1698-1700.

41. R. Kelly and P. J. Padley, Photometric Studies in Hydrogen + Oxygen + Carbon Dioxide Flames, Trans. Faraday Soc. 67 (1971), 740-49.

42. D. D. Jackson, Thermodynamics of the Gaseous Hydroxides, UCRL-51137, Lawrence Livermore Laboratory, 1970.

43. O. H. Krikorian, Thermodynamics of the Silica-Steam System, Presented at Symposium on Engineering with Nuclear Explosives, CONF-700101, May 1970.

44. B. B. Ebbinghaus, Thermodynamics of Gas Phase Chromium Species: The Chromium Oxides, the Chromium Oxyhydroxides, and Volatility Calculations in Waste Incineration Processes, Comb. and Flame 93 (1993), 119-37.

45. M. W. Chase, NIST-JANAF Thermochemical Tables, Journal of Physical and Chemical Reference Data, Monograph No. 9, American Institute of Physics, Woodbury, New York, 1999.

46. L. V. Gurvich, V. S. Iorish, D. V. Chekhovskoi, and V. S. Yungman, IVTANTHERMO-A Thermodynamic Database and Software System for the Personal Computer, NIST Special Database 5, U. S. Department of Commerce, Gaithersburg, MD, 1993.

47. C. W. Bauschlicher, Jr., S. R. Langhoff, and H. Partridge, "Ab initio study of the alkali and alkaline-earth monohydroxides," J. Chem. Phys. 84, 901-9 (1986).

48. M. D. Allendorf, C. F. Melius, P. Ho, and M. R. Zachariah, Theoretical Study of the Thermochemistry of Molecules in the Si-O-H System, J. Phys. Chem. 99 (1999), 15284-93. 
49. R. L. Kuckowski, D. R. Lide, Jr., and L. C. Krisher, Microwave Spectra of Alkali Hydroxides: Evidence for Linearity of $\mathrm{CsOH}$ and $\mathrm{KOH}, \mathrm{J}$. Chem. Phys. 44 (1966), 3131-32.

50. C. J. Whitham, J. Ozeki, and S. Saito, "Microwave spectroscopic detection of transition metal hydroxides: $\mathrm{CuOH}$ and AgOH," J. Chem. Phys. 110 (1999), 11109-112.

51. G. Elliot, Gaseous Hydrated Oxides, Hydroxides, and other Hydrated Molecules, UCRL-1831, PhD Thesis, University of California at Berkeley, 1952.

52. T. Greene, S. P. Randall, and J. L. Margrave, Characterization of Unusual Gaseous Oxide and Hydroxide Molecules in M-O-H Systems at High Temperatures, in Thermodynamic and Transport Properties of Gases, Am. Soc. Mech. Eng., 1959, pp. 222-25. 
Vapor Species over Chromia

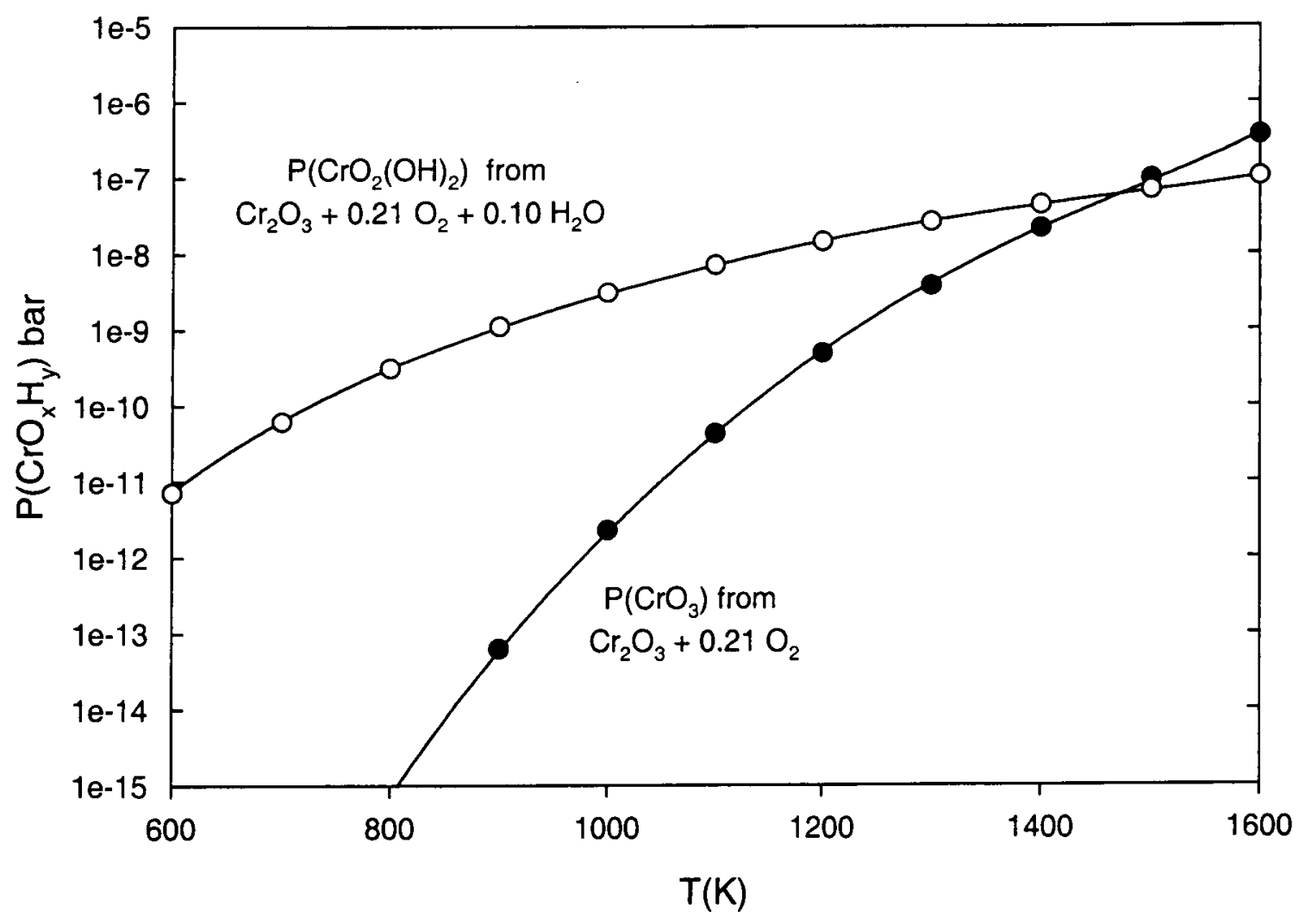

Figure 1. Calculated vapor pressures of dominant species over $\mathrm{Cr}_{2} \mathrm{O}_{3}$. Data is from reference [34, 44, and 45] 


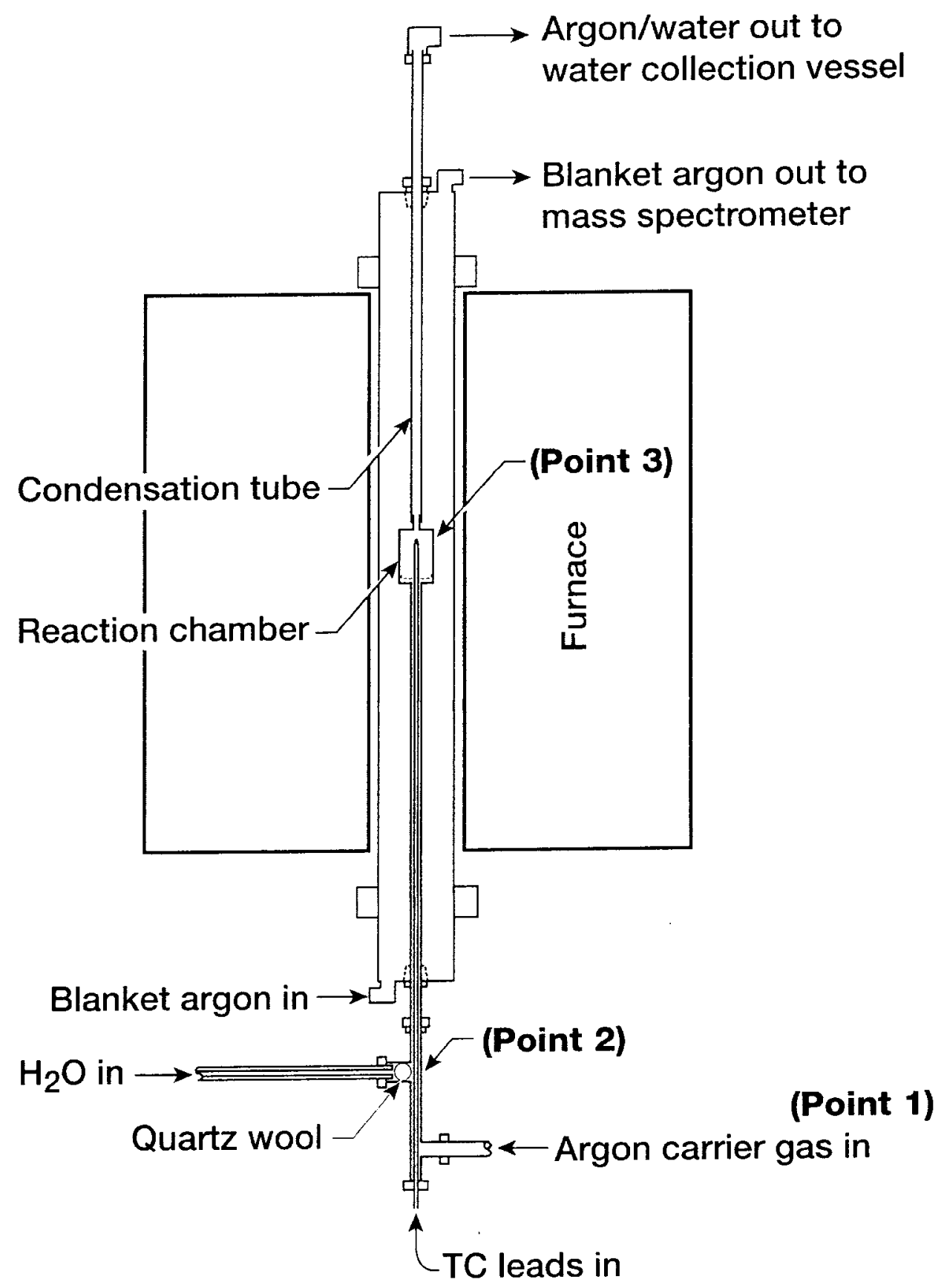

CD-03-82425

Figure 2. Schematic of our transpiration system. 


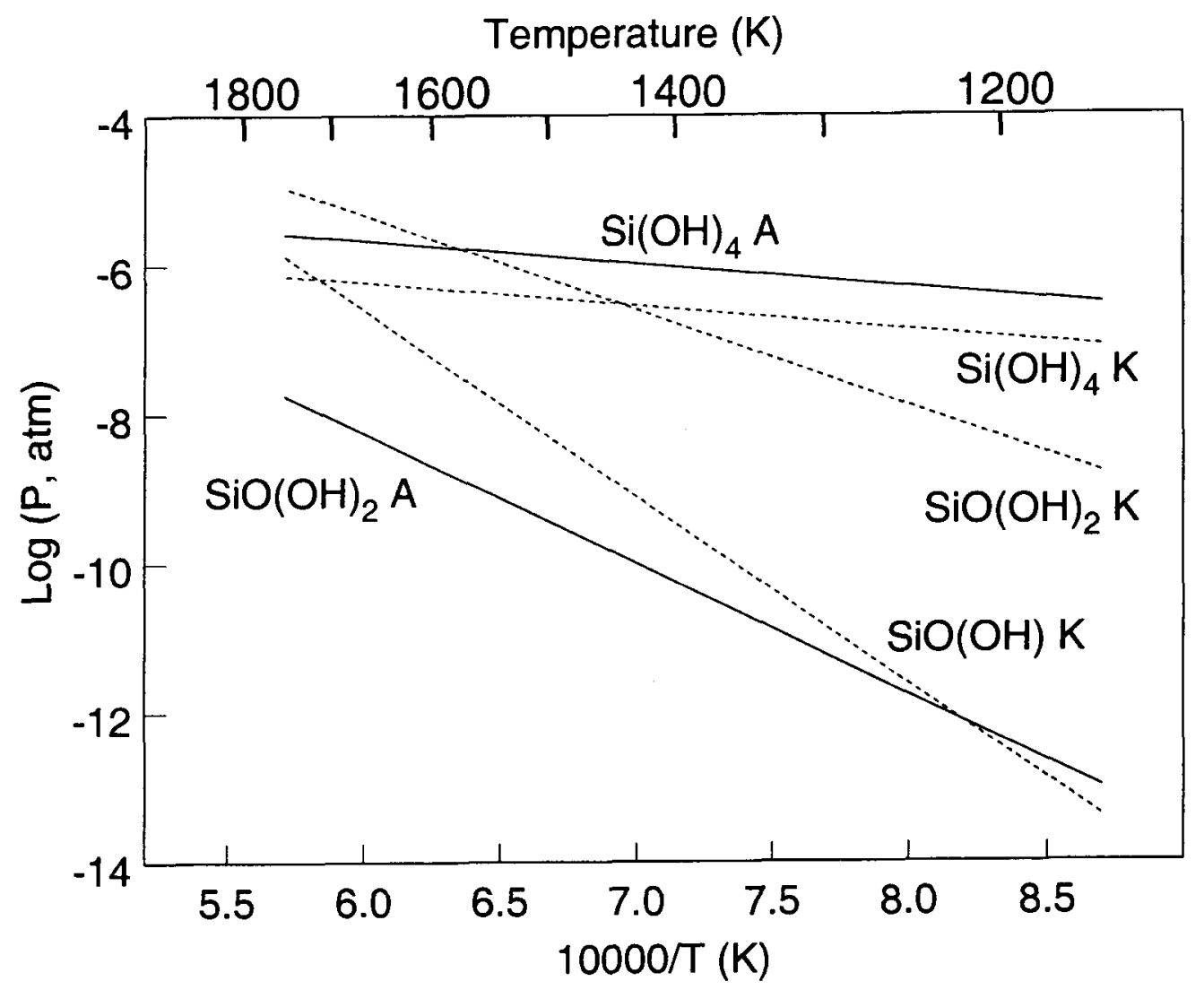

Figure 3. Calculated vapor pressure of $\mathrm{Si}-\mathrm{OH}$ species over $\mathrm{SiO}_{2}$ with $\mathrm{x}\left(\mathrm{H}_{2} \mathrm{O}\right)=$ 0.37 and $P($ total $)=1$ bar. The lines labeled $\mathrm{K}$ were calculated from thermodynamic functions taken from Krikorian's estimates based on the pseudo halide behavior of the hydroxyl group. The lines labeled A were calculated from the thermodynamic functions taken from Allendorf's ab initio calculations. 


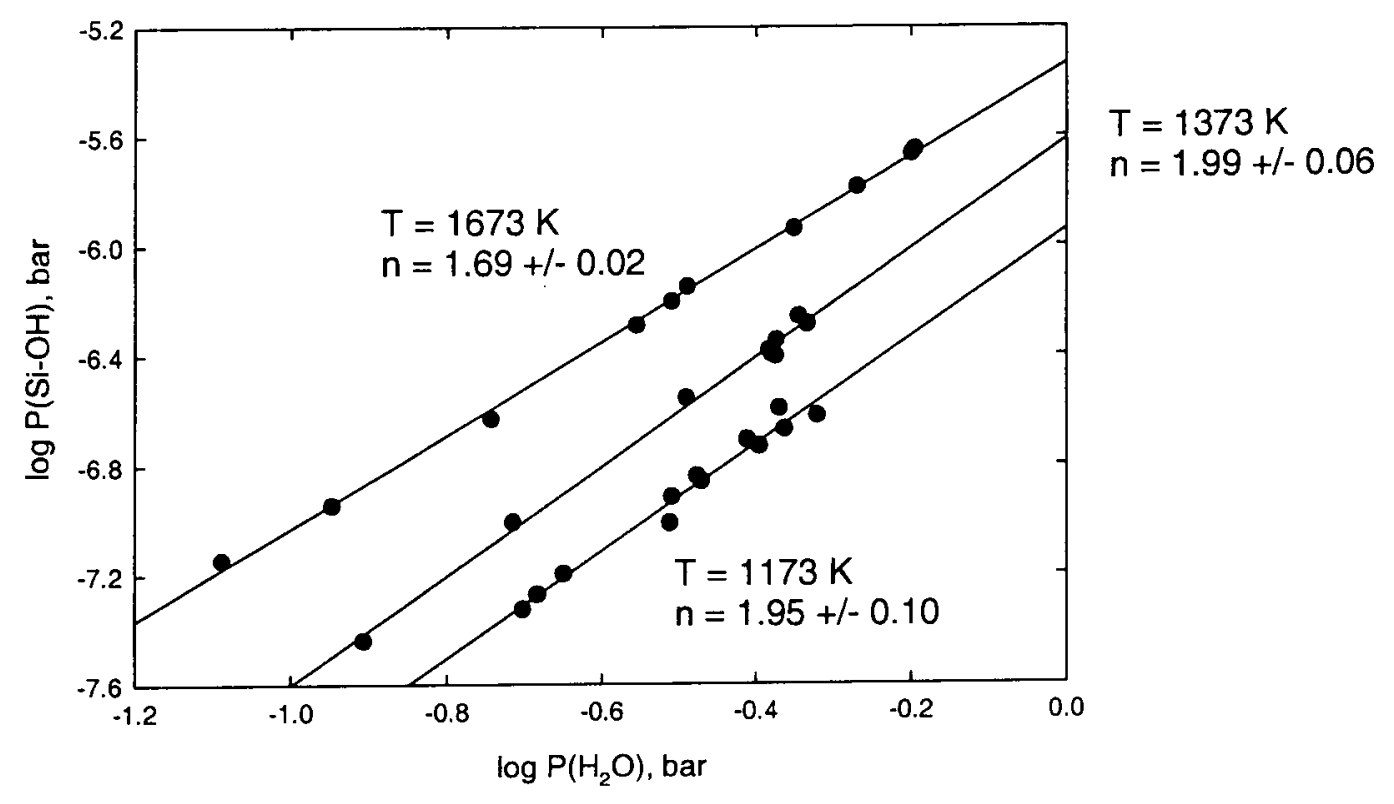

Figure 4. Pressure dependence of Si-OH formation. 


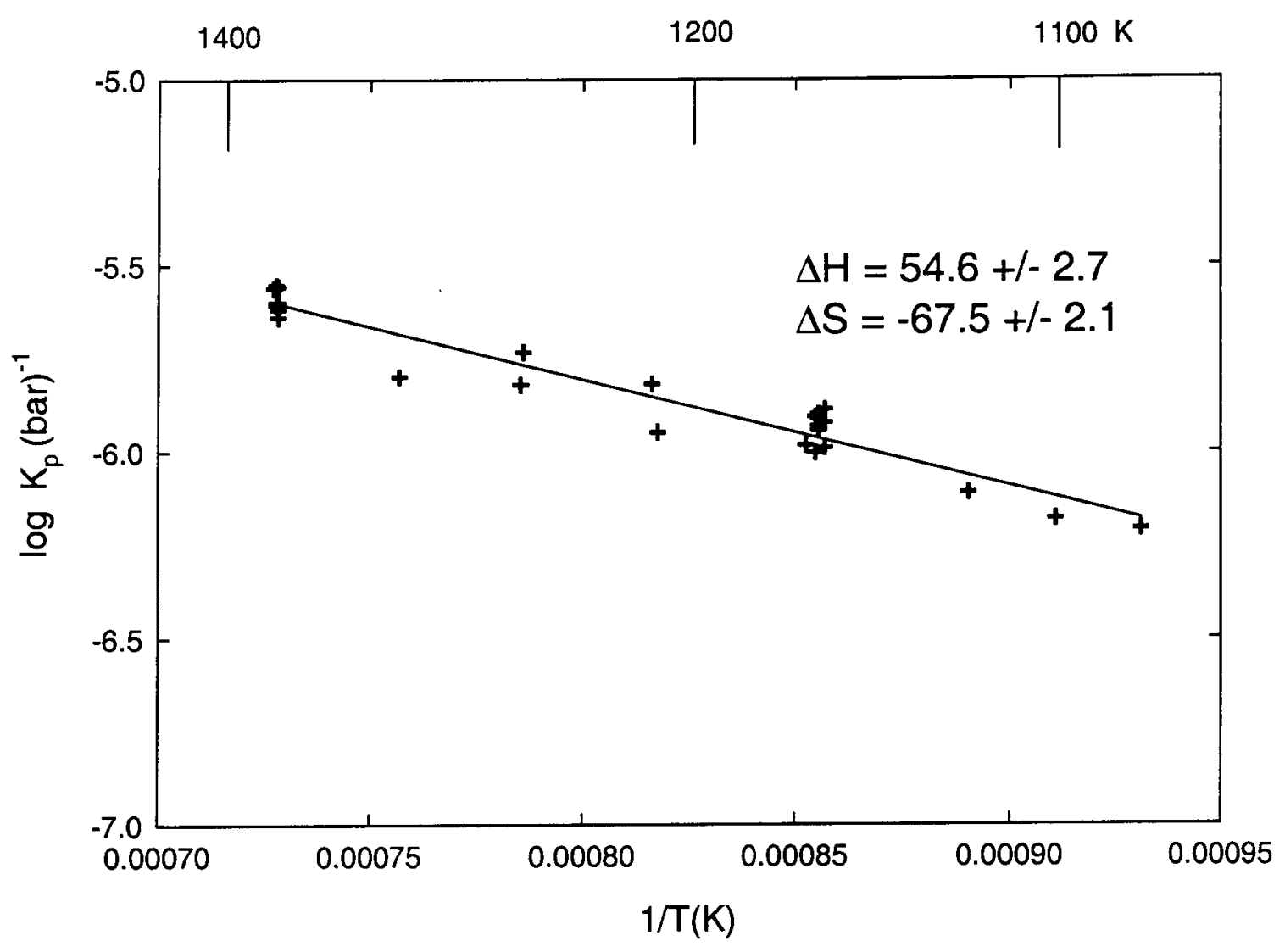

Figure 5. Plot of $\ln \mathrm{K}_{\mathrm{p}}$ vs $1 / \mathrm{T}$ for $\mathrm{SiO}_{2}(\mathrm{~s})+2 \mathrm{H}_{2} \mathrm{O}(\mathrm{g})=\mathrm{Si}(\mathrm{OH})_{4}(\mathrm{~g})$. 